Tropical Journal of Pharmaceutical Research March 2021; 20 (3): 633-638

ISSN: $1596-5996$ (print); 1596-9827 (electronic)

(C) Pharmacotherapy Group, Faculty of Pharmacy, University of Benin, Benin City, 300001 Nigeria.

\title{
Radiosensitizing effect of polysaccharide in Schisandrae chinensis (Turcz.) Baill. Fruit on ovarian cancer SKOV3 cells
}

\author{
Cai-Xia Wang, Dan Wan*, Shi-Cong Qiao, Min Xia, Ya-Ting Duan \\ Traditional Chinese Medicine Gynecology, Chongqing Hospital of Traditional Chinese Medicine, Chongqing 400021, China
}

*For correspondence: Email: wandantcn@163.com

Sent for review: 16 April 2020

Revised accepted: 20 February 2021

\begin{abstract}
Purpose: To investigate the radiosensitizing effect of polysaccharide from Schisandrae Chinensis fruit (SCFP) on ovarian cancer SKOV3 cell line.

Methods: The 3-(4,5-dimethylthiazol-2-yl)-2,5-diphenyltetrazolium bromide (MTT) assay was used to evaluate SKOV3 cell viability. Caspase-3, caspase-9, Bax, and Bcl-2 levels in SKOV3 cells were assessed by enzyme-linked immunosorbent assay (ELISA). Furthermore, mRNA expression of caspase-3, caspase-9, Bax and Bcl-2 in SKOV3 cells were determined using quantitative real-time polymerase chain reaction (RT-qPCR) assay.

Results: $\beta$-Irradiation (10 Gy) did not show obvious inhibitory effects on SKOV3 cell proliferation. However, SCFP at a dose of $1.25,2.5$ and $5 \mathrm{mg} / \mathrm{mL}$ significantly enhanced the radiosensitivity of SKOV3 cells to $\beta$-irradiation ( $p<0.01$ ). Furthermore, SCFP at concentrations of $1.25,2.5$ and $5 \mathrm{mg} / \mathrm{mL}$ significantly increased the levels of caspase-3, caspase-9 and Bax in SKOV3 cells, but decreased that of $\mathrm{BCl}-2(p<0.01)$. In addition, SCFP combined with $\beta$-irradiation up-regulated mRNA expression of caspase-3, caspase- 9 and Bax $(p<0.01)$, but down-regulated that of Bcl-2 in SKOV3 cells $(p<0.01)$. Conclusion: SCFP significantly enhances the sensitivity of nasopharyngeal carcinoma SKOV3 cells to $\beta$-irradiation. The possible mechanism of sensitization might be correlated to the induction of mitochondria-mediated apoptosis. This research provides a scientific basis for the development of SCFP for the treatment of ovarian cancer.
\end{abstract}

Keywords: Radiosensitizing, Polysaccharide, Schisandrae chinensis fructus, $\beta$-Irradiation, Ovarian cancer, SKOV3 cell line

This is an Open Access article that uses a fund-ing model which does not charge readers or their institutions for access and distributed under the terms of the Creative Commons Attribution License (http://creativecommons.org/licenses/by/4.0) and the Budapest Open Access Initiative (http://www.budapestopenaccessinitiative.org/read), which permit unrestricted use, distribution, and reproduction in any medium, provided the original work is properly credited.

Tropical Journal of Pharmaceutical Research is indexed by Science Citation Index (SciSearch), Scopus, International Pharmaceutical Abstract, Chemical Abstracts, Embase, Index Copernicus, EBSCO, African Index Medicus, JournalSeek, Journal Citation Reports/Science Edition, Directory of Open Access Journals (DOAJ), African Journal Online, Bioline International, Open-J-Gate and Pharmacy Abstracts

\section{INTRODUCTION}

Ovarian cancer has been reported to be the fifth leading cause of oncological-related death in women in the last four decades. In the last 40 years, the mortality rates for ovarian cancer have not significantly declined, with the estimated deaths in 2020 being $5 \%$ of all cancer types [1]. The current treatments for ovarian cancer are mainly chemotherapy and surgery. As an important part of biotherapy, traditional Chinese medicine (TCM) can improve immunity and anticancer ability in patients, reduce the side effects of radiotherapy and chemotherapy, and improve 
the sensitivity of patients to radiotherapy and chemotherapy [2]. In addition, the possible mechanisms of TCM ovarian cancer treatments include inhibiting tumor cell proliferation by inducing apoptosis, regulating body immunity, and improving the sensitivity of chemotherapy drugs [2].

Schisandrae Chinensis Fructus (SCF), or Beiweizi in Chinese, is the dried mature fruit of the Schisandra chinensis (Turcz.) Baill. plant, and this fruit is a well-known herbal medicine in China that is commonly used to treat cough, asthma, enuresis, persistent diarrhea, and insomnia [3]. Modern investigations have demonstrated that SCF contains different constituents, including lignans, volatile oils, organic acids, terpenes, flavonoids, and polysaccharides. Modern pharmacology has also shown that SCF possesses antitumor, antioxidant, hepatoprotective, and cardiovascular protective activities [4]. In recent years, several studies have reported that macromolecular compounds, particularly polysaccharides, possess antitumor, antioxidant, and immunoregulatory bioactive effects [5]. It has been reported that polysaccharides in SCF (SCFP) inhibit the proliferation of ovarian cancer SKOV3 cells [6], although the mechanism is unclear. Therefore, the present study aimed to analyze the radiosensitizing effect of SCFP on ovarian cancer SKOV3 cells and determine its possible underlying mechanism

\section{EXPERIMENTAL}

\section{Chemicals and reagents}

The 3-(4,5-dimethylthiazol-2-yl)-2,5diphenyltetrazolium bromide (MTT) and DMSO were purchased from Sigma Co. (Shanghai, China). Caspase-3, caspase-9, Bax, and Bcl-2 enzyme-linked immunosorbent assay (ELISA) kits were obtained from Beyotime Institute of Biotechnology (Shanghai, China). RPMI 1640 medium and FBS were purchased from Gibco Biotech. (Shanghai, China). RNA (Ribonucleic Acid) TRIzol Reagent was purchased from Servicebio Company (Wuhan, China). RevertAid First Strand cDNA Synthesis Kit was obtained from Thermo Fisher (MO, USA). All other reagents used in the experiments were of analytical grade.

\section{Polysaccharide extraction from SCF}

SCF (Schisandrae Chinensis Fructus) was processed into a powder and exhaustively extracted with $95 \%$ ethanol for $12 \mathrm{~h}$ to remove pigments, monosaccharides, and small-molecule materials. The residue was air-dried and extracted in distilled water by refluxing. The extract was left to cool at room temperature, filtered, and concentrated to one-tenth the original volume. Then, ethanol was added slowly to a final concentration of $80 \%$ and this solution was incubated at $4{ }^{\circ} \mathrm{C}$ overnight. After incubation, the precipitates were collected by filtering the solution, and were then washed three times with pure ethanol and acetone before being dried at $50{ }^{\circ} \mathrm{C}$ to obtain the crude polysaccharides (SCFP). The polysaccharide content in SCFP was $84.12 \%$.

\section{Cell culture and $\beta$-irradiation}

Ovarian cancer SKOV3 cell line was obtained from Shanghai SuRan Biotechnology Co., Ltd. SKOV3 cells were cultured in RPMI1640 supplemented with $10 \%$ FBS and grown in an incubator with $5 \% \mathrm{CO}_{2}$ at $37{ }^{\circ} \mathrm{C}$. The cells were exposed to $\beta$-ray irradiation at serial or designed doses using a 2300 C/D linear accelerator (Varian, USA).

\section{MTT assay}

Cell viability was evaluated using the 3-(4,5dimethylthiazol-2-yl)-2,5-diphenyltetrazolium bromide (MTT) assay. SKOV3 cells $\left(1 \times 10^{4}\right.$ cells/well) were seeded in a 96-well plate and cultured for $24 \mathrm{~h}$. Then, cells were exposed to different concentrations of SCFP for $24 \mathrm{~h}$. For the radiosensitivity assay, SKOV3 cells were exposed to $\beta$-irradiation in addition to the SCFP treatment. Optical density (OD) values were measured at $490 \mathrm{~nm}$ using a Multlskan Mk3 microplate reader (Thermo Fisher, Waltham, MA, USA). The experiment was repeated three times. Cell viability was expressed as the OD percentage of normal (untreated) cells.

\section{ELISA assay}

After SCFP and $\beta$-irradiation treatment, the supernatant of SKOV3 cells was harvested. Then, commercial ELISA kits were used to determine the levels of caspase-3, caspase-9, Bax, and Bcl-2 according to the manufacturer' $s$ instructions.

\section{Quantitative real-time polymerase chain reaction (RT-qPCR)}

Total RNA from the SKOV3 cells was extracted using RNA TRIzol Reagent according to the manufacturer's instructions. Sample purity and concentration were determined according to their absorbance at 260 and $280 \mathrm{~nm}$. Then, $2 \mu \mathrm{g}$ RNA was reverse transcribed into cDNA using the 
RevertAid First Strand cDNA Synthesis Kit according to the manufacturer's instructions. RTqPCR was performed using an $A B I$ StepOnePlus System (Applied Biosystems, CA, USA). The reaction process for the $\mathrm{RT}$-qPCR was as follows: $95{ }^{\circ} \mathrm{C}$ for $30 \mathrm{~s}$, cycles of $95{ }^{\circ} \mathrm{C}$ for $5 \mathrm{~s}$ and $55^{\circ} \mathrm{C}$ for $30 \mathrm{~s}$, and a final extension at $72{ }^{\circ} \mathrm{C}$ for $30 \mathrm{~s}$. The expression levels of caspase-3, caspase-9, Bax, and Bcl-2 were normalized to $\beta$ actin and analyzed using the $2-\triangle \triangle \mathrm{CT}$ method.

\section{Statistical analysis}

All the data are expressed as mean \pm standard deviation (SD). The student's $t$-test was used to evaluate the significance of differences observed in the results. Differences were considered statistically significant at $p \leq 0.05$.

\section{RESULTS}

\section{Antitumor effects of SCFP and $\beta$ irradiation} on cell proliferation of SKOV3 cells

The MTT assay was conducted to identify relative sub-toxic doses of SCFP and $\beta$ irradiation in SKOV3 cells. We found that SCFP treatment at doses of $10(p<0.05), 20$ ( $p<$ $0.01)$, and $40 \mathrm{mg} / \mathrm{mL}(p<0.01)$ exerted significant cytotoxicity on SKOV3 cells (Figure 1). Additionally, $\beta$-ray irradiation also showed notable cytotoxicity on SKOV3 cells at doses greater than $10 \mathrm{~Gy}$ (Figure 2). Based on these results, the $\beta$-ray irradiation at $10 \mathrm{~Gy}$ and 1.25 , 2.5 , and $5 \mathrm{mg} / \mathrm{mL}$ SCFP treatment were selected for subsequent experimentation.

\section{SCFP enhanced radio-sensitivity of SKOV3 cells to $\beta$ irradiation}

The reported cytotoxicity of $\beta$-irradiation and $\operatorname{SCFP}(1.25,2.5$, and $5 \mathrm{mg} / \mathrm{mL})$ combined treatment on SKOV3 cells is presented in Figure 3 . We found that $10 \mathrm{~Gy} \beta$-irradiation did not have significant inhibitory effects on the proliferation of SKOV3 cells $(p>0.05)$. Interestingly, SCFP treatment at concentrations of $1.25(p<0.05)$, $2.5(p<0.01)$, and $5 \mathrm{mg} / \mathrm{mL}(p<0.01)$ significantly enhanced the radiosensitivity of SKOV3 cells to 10 Gy $\beta$-irradiation treatment.

Effect of SCFP on the protein expression of caspase-3, caspase-9, Bax, and Bcl-2 in SKOV3 cells

To explore the possible mechanism of the enhanced radiosensitivity of SCFP, proteins related to the apoptosis pathway, including caspase-3, caspase-9, Bax, and Bcl-2 were detected in SKOV3 cells using an ELISA assay.

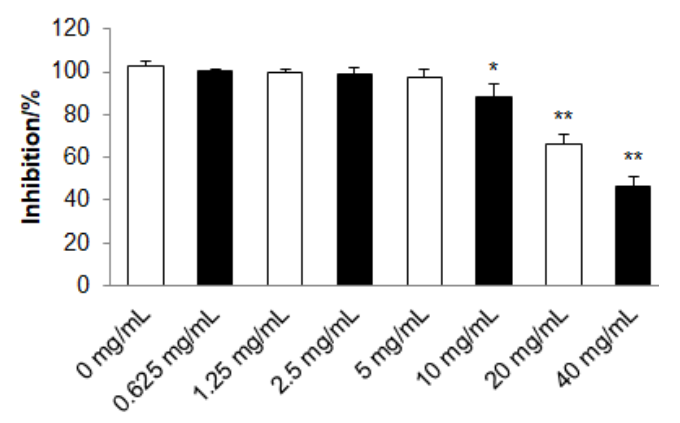

Figure 1: Effect of SCFP on proliferation of SKOV3 cells. Data are expressed as mean $\pm \mathrm{SD}(n=4) ;{ }^{*} p<$ $0.05,{ }^{* *} p<0.01$, compared with control group

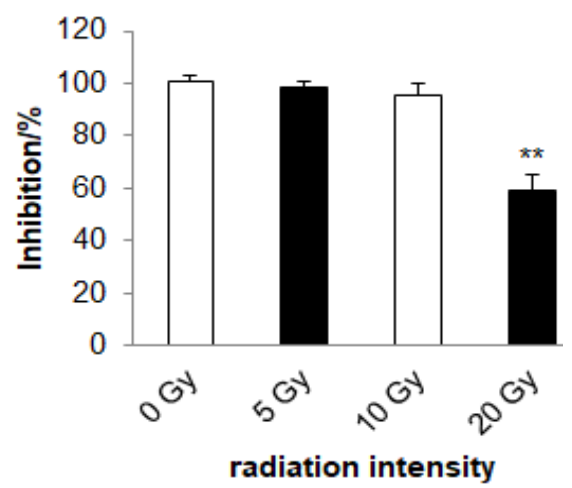

Figure 2: Effect of $\beta$ irradiation on proliferation of SKOV3 cells. Data are expressed as mean \pm SD $(n=$ 4 ); ${ }^{*} p<0.05,{ }^{* *} p<0.01$, compared with control group

Table 1: The sequence of primers used

\begin{tabular}{lccc}
\hline Name & Upstream gene & Downstream gene & $\begin{array}{c}\text { Gene } \\
\text { length }\end{array}$ \\
\hline -actin & GAAGATCAAGATCATTGCTCC & TACTCCTGCTTGCTGATCCA & $111 \mathrm{bp}$ \\
Caspase 3 & GCACTGGAATGTCAGCTCGCAATG & TTCAGGTCCACAGGTCCGTTCGTT & $238 \mathrm{bp}$ \\
Caspase 9 & CCTCATCATCAACAACGTGAACTT & TTTTCTTAGCAGTCAGGTCGTTC & $146 \mathrm{bp}$ \\
Bax & GGCGAATTGGCGATGAACTGGACAAC & GCTGCCACACGGAAGAAGACCTCTC & $100 \mathrm{bp}$ \\
Bcl-2 & ACGGTGGTGGAGGAACTCTTCAGG & AGCGTCTTCAGAGACAGCCAGGAG & $266 \mathrm{bp}$ \\
\hline
\end{tabular}




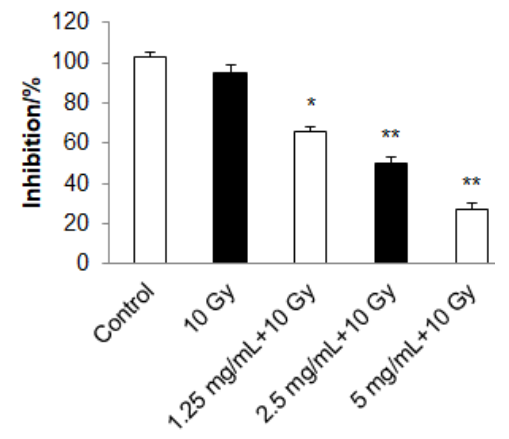

Figure 3: Effects of SCFP combined with $\beta$ irradiation on cell proliferation of SKOV3 cell. Data are expressed as mean $\pm \operatorname{SD}(\mathrm{n}=4) ;{ }^{*} p<0.05,{ }^{* *} p<0.01$, compared with control group

As shown in Figure 4, the levels of caspase-3, caspase-9, and Bax significantly increased in SKOV3 cells treated with $1.25,2.5$, and $5 \mathrm{mg} / \mathrm{mL}$ SCFP in combination with $\beta$-irradiation $(p<$ 0.05 ), whereas the level of $\mathrm{Bcl}-2$ significantly decreased in SKOV3 cells subjected to the same treatment $(p<0.05)$.

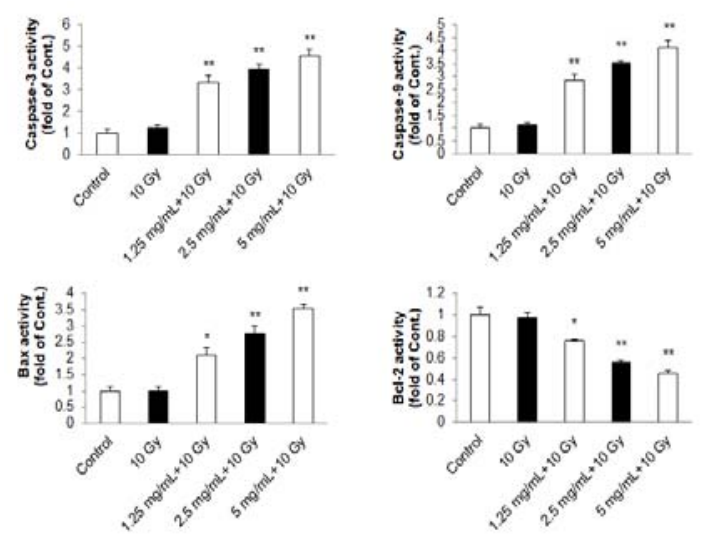

Figure 4: Effect of SCFP combined with $\beta$ irradiation on protein expression of caspase-3, caspase-9, Bax and $\mathrm{Bcl}-2$ in SKOV3 cells. Data are expressed as mean $\pm \mathrm{SD}(\mathrm{n}=4) ;{ }^{*} p<0.05,{ }^{* *} p<0.001$, compared with control group

Effect of SCFP on mRNA expression of caspase-3, caspase-9, Bax, and Bcl-2 in SKOV3 cells

The mRNA expression of caspase-3, caspase-9, $\mathrm{Bax}$, and $\mathrm{Bcl}-2$ in SKOV3 cells treated with SCFP are shown in Figure 6. We found that mRNA expression of these genes significantly increased after $1.25,2.5$, and $5 \mathrm{mg} / \mathrm{mL}$ SCFP treatment when combined with $\beta$-irradiation $(p<0.01)$, whereas the expression of $\mathrm{BCl}-2$ decreased in SKOV3 cells subjected to the same treatment $(p$ $<0.01$ ).
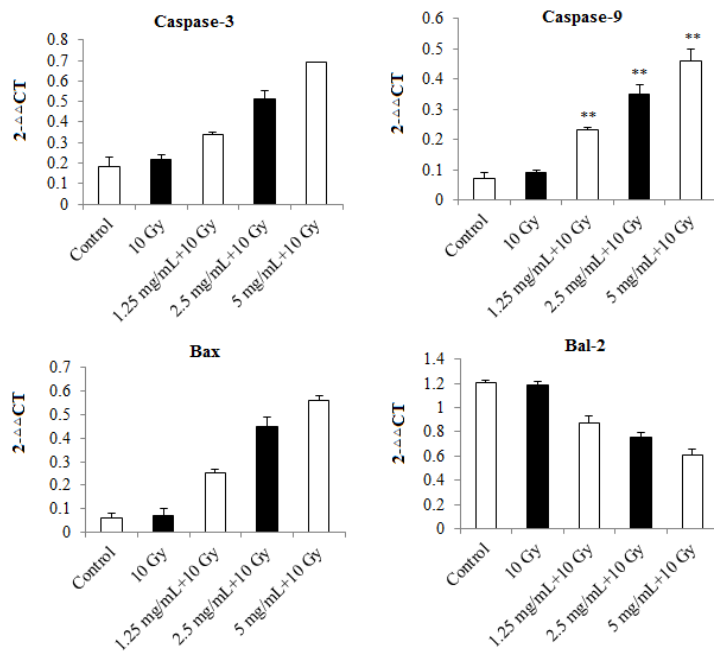

Figure 5: Effect of SCFP combined with $\beta$ irradiation on mRNA expression of caspase-3, caspase-9, Bax and $\mathrm{Bcl}-2$ in SKOV3 cells. Data are expressed as mean \pm SD $(\mathrm{n}=4) ;{ }^{*} p<0.05,{ }^{* *} p<0.01$, compared with Control group; ${ }^{\#} p<0.01$, compared with control group $(0 \mathrm{mg} / \mathrm{mL})$

\section{DISCUSSION}

Radiotherapy is a common method for treating solid tumors in addition to surgery; however, over $10 \%$ of tumors show resistance to the radiotherapy $[7,8]$ and significantly limit its therapeutic effect. Radiosensitizers are considered a feasible approach to reverse this radio-resistance $[9,10]$. The results of the present investigation demonstrated that SCFP treatment could significantly sensitize SKOV3 cells to $\beta$-ray irradiation and that apoptosis-related mechanism could be involved in its effect [11].

The possible mechanisms of radiosensitizers are complex, and can include apoptosis, DNA damage, and cell cycle arrest [11]. Apoptosis is important for programmed cell death, which is crucial for oncotherapy $[12,13]$. Caspase family proteins are the executors of cell apoptosis. Caspase- 9 initiates the caspase cascade reaction, which can be activated by the release of cytochrome c. Once caspase-9 is activated, caspase- 3 is subsequently activated, which acts as a crucial death protease $[14,15]$. In addition, caspase- 3 activates the other caspase proteins, resulting in a cascade reaction $[9,15]$.

Bax directly promotes the release of cytochrome $\mathrm{C}$ into the cytoplasm and inhibits anti-apoptotic $\mathrm{Bcl}-2$ proteins [16]. Bcl-2 is a known apoptosis inhibitory factor that suppresses the release of cytochrome $c$ into the cytoplasm $[17,18]$. In the present study, when SCFP treatment was 
combined with $\beta$-ray irradiation, the protein and mRNA expression of caspase 3 , caspase 9 , and Bax increased, while those of Bcl-2 decreased in SKOV3 cells. These results demonstrated that the antitumor mechanism of the SCFP and $\beta$-ray irradiation combined treatment is related to the induction of mitochondria-mediated apoptosis.

\section{CONCLUSION}

SCFP enhances the sensitivity of ovarian cancer SKOV3 cells to $\beta$-irradiation. The mechanism of action is potentially related to the induction of mitochondria-mediated apoptosis. The findings of this research may support the use of SCFP for the clinical management of ovarian cancer; however, further studies are required to confirm these results.

\section{DECLARATIONS}

\section{Acknowledgement}

This work was supported by the National Key Research and Development Program of China (no. 2018YFC1704104).

\section{Conflict of interest}

No conflict of interest is associated with this work.

\section{Contribution of authors}

We declare that this work was done by the authors named in this article and all liabilities pertaining to claims relating to the content of this article will be borne by the authors. Cai-Xia Wang and Shi-Cong Qia contributed equally to this manuscript. The authors declare that this work was done by the authors named in this article and all liabilities pertaining to claims relating to the content of this article will be borne by them.

\section{Open Access}

This is an Open Access article that uses a funding model which does not charge readers or their institutions for access and distributed under the terms of the Creative Commons Attribution License (http://creativecommons.org/licenses/by/ 4.0) and the Budapest Open Access Initiative (http://www.budapestopenaccessinitiative.org/rea d), which permit unrestricted use, distribution, and reproduction in any medium, provided the original work is properly credited.

\section{REFERENCES}

1. Siegel RL, Miller KD, Jemal A. Cancer statistics, 2018. CA: A Cancer J Clinicians 2018; 68(1): 7-30.

2. Zhao YL, Song JN, Zhang TS, Wei YY, Guo XQ, Wang $Y$. Research progress of anti-ovarian carcinoma effect of effective components in traditional Chinese medicine. J Log Univ PAP (Med Sci) 2017; 26 (11): 1005-1009.

3. Chinese Pharmacopoeia Commission. Pharmacopoeia of the People's Republic of China Part I; Beijing: People's Medical Publishing House; 2015; $p 67$.

4. Bai WY, Wang HE, WangBY, Yu HS, Li Z. Research Progress on chemical constituents and pharmacological action of Schisandrae Chinensis Fructus. Chin Trad Pat Med 2019; 41 (9): 2177-2183.

5. Hu MB, Peng W, Liu YJ, Wu N, Zhao CB, Xie DS, Yan D, Zhang $X F$, Tao $X B$, Wu CJ. optimum extraction of polysaccharide from areca catechu using response surface methodology and its antioxidant activity. J Food Process Pres 2017; 41: e12798

6. Lai YM, Xu N, Chen XJ, Wang N, Ding Y, Zhang Y, Tian $H$. Study of Inhibitory Effect of $S$ chisandra $C$ hinensis Polysaccharide on Proliferation of Ovarian Cancer SKOV3 Cells. Chin Arch Trad Chin Med 2014; 32 (4): 856-857.

7. Borchiellini D, Etienne-Grimaldi MC, Thariat J, Milano G. The impact of pharmacogenetics on radiation therapy outcome in cancer patients. A focus on DNA damage response genes. Cancer Treat Rev 2012; 38: 737-759.

8. Zhao WY, Sun XC. Progression of tumor radiosensitization. Chin Clin Oncol 2012; 17: 655-659.

9. Wang X, Li Q, Jin H, Zou H, Xia W, Dai N, Dai XY, Wang $D$, $X u$ CX, Qing Y. miR-424 acts as a tumor radiosensitizer by targeting aprataxin in cervical cancer. Oncotarget. 2016, doi: 10.18632/oncotarget.12716.

10. Baek SJ, Sato K, Nishida N, Koseki J, Azuma R, Kawamoto K, Konno M, Hayashi K, Satoh T, Doki Y. MicroRNA miR-374, a potential radiosensitizer for carbon ion beam radiotherapy. Oncol Rep 2016; 36 : 2946-2950.

11. Dai Y, Liu M, Tang W, DeSano J, Burstein E, Davis M, Pienta K, Lawrence $T$, Xu L. Molecularly targeted radiosensitization of human prostate cancer by modulating inhibitor of apoptosis. Clin Cancer Res 2008; 14: 7701-7710.

12. Galluzzi L, Zamzami N, de La Motte Rouge T, Lemaire $C$, Brenner C, Kroemer G. Methods for the assessment of mitochondrial membrane permeabilization in apoptosis. Apoptosis 2007; 12:803-813.

13. Qi F, Li A, Zhao L, Xu H, Inagaki Y, Wang D, Cui X, Gao $B$, Kokudo N, Nakata M. Cinobufacini, an aqueous extract from Bufo bufo gargarizans Cantor, induces apoptosis through a mitochondria-mediated pathway in human hepatocellular carcinoma cells. J Ethnopharmacol 2010; 128:654-661.

14. Xia LF, Liang SH, Wen H, Tang J, Huang Y. Anti-tumor effect of polysaccharides from rhizome of Curculigo 
orchioides Gaertn on cervical cancer. Trop J Pharm Res 2016; 15: 1731-1737.

15. Gao N, Budhraja A, Cheng S, Yao H, Zhang Z, Shi X. Induction of apoptosis in human leukemia cells by grape seed extract occurs via activation of c-Jun NH2-terminal kinase. Clin Cancer Res 2009; 15 (1): 140-149.

16. Chipuk JE, McStay GP, Bharti A, Kuwana T, Clarke CJ, Siskind LJ, Obeid LM, Green DR. Sphingolipid metabolism cooperates with Bak and Bax to promote the mitochondrial pathway of apoptosis. Cell 2012; 148(5): 988-1000.

17. Wang $X D$. The expanding role of mitochondria in apoptosis. Genes Dev. 2001; 15: 2922-2933.

18. Park HJ, Jeon YK, You DH, Nam MJ. Daidzein causes cytochrome c-mediated apoptosis via the Bcl-2 family in human hepatic cancer cells. Food Chem Toxicol 2013; 60: 542-549. 